\title{
PELATIHAN AKUNTANSI PERBANKAN KEPADA GURU-GURU SMK KETINTANG SURABAYA
}

\section{BANKING ACCOUNTING TRAINING FOR TEACHER OF VOCATIONAL HIGH SCHOOL OF KETINTANG SURABAYA}

\author{
${ }^{1}$ Sudjarno Eko Supriyono, ${ }^{2)}$ Evi Sistiyarini, ${ }^{3)}$ Dewi Murdiawati \\ ${ }^{1)}$ Program Studi Diploma 3 Keuangan dan Perbankan, Fakultas Ekonomi \\ ${ }^{2)}$ Program Studi Sarjana Manajemen, Fakultas Ekonomi \\ ${ }^{3)}$ Program Studi Sarjana Akuntansi, Fakultas Ekonomi \\ Sekolah Tinggi Ilmu Ekonomi Surabaya \\ Kampus 1, JL. Nginden Semolo Nomor 34-36 Surabaya \\ Kampus 2, JL. Wonorejo Utara Nomor 16 Surabaya \\ *Email: ${ }^{1)}$ supriyono@perbanas.ac.id, ${ }^{2)}$ evi.sistiyarini@perbanas.ac.id, \\ ${ }^{3)}$ dewi.murdiawati@perbanas.ac.id
}

\begin{abstract}
ABSTRAK
Permasalahan yang dihadapi oleh SMK Ketintang Surabaya adalah sistem pembelajaran akuntansi perbankan yang masih terbatas dan dilakukan secara manual. Kegiatan ini diikuti oleh guru akuntansi SMK Ketintang Surabaya. Tujuan dari kegiatan ini adalah meningkatkan kemampuan guru SMK Ketintang Surabaya tentang akuntansi perbankan yang ada di Bank Konvensional. Metode pengabdian masyarakat yang dilakukan adalah berupa pelatihan transaksi akuntansi bank baik secara teori maupun secara praktek mulai dari pengisian slip transaksi sampai dengan input transaksi menggunakan software perbankan konvensional. Hasil pengabdian ini adalah para guru mendapatkan materi tentang transaksi akuntansi perbankan secara praktek. Materi yang diberikan pada saat pelatihan teridiri dari transaksi penghimpunan dana (produk giro, tabungan dan deposito), transaksi penyaluran dana (kredit) dan transaksi jasa bank (transfer). Dalam pelatihan ini, para guru praktek untuk mengisi slip transaksi perbankan, membuat jurnal transaksi akuntansi bank serta melakukan input pada komputer. Pentingnya kegiatan ini adalah adanya tambahan pengetahuan transaksi tentang akuntansi perbankan sehingga para guru juga dapat mentransfer ilmu kepada para siswa.
\end{abstract}

Kata kunci: Pelatihan; Akuntansi; Perbankan; SMK

\begin{abstract}
The problem faced by Ketintang Vocational High School Surabaya is a banking accounting learning system that is still limited and is done manually. This activity followed by accounting teachers of Ketintang Vocational High School Surabaya. The purpose of this activity is to improve the ability of Ketintang Vocational High School Surabaya teachers about banking accounting in Conventional Banks. The community service method used training in bank accounting transactions both in theory and in practice starting from filling transaction slips until input all of the transaction using conventional banking software. The result of this community service is the teachers get material about banking accounting transactions in practice. The material provided during training consists of fund raising transactions (current accounts, savings and time deposits), fund distribution (credit) transactions and bank service transactions (transfers). In this training, the teachers practice to fill in banking transaction slips, keep a journal of bank account transactions and input on the computer. The importance of this activity is the addition of transaction knowledge about banking accounting so that teachers can also transfer knowledge to students.
\end{abstract}

Keywords: Training; Accounting; Banking; School

Submitted : 1 Agustus 2019 Revision : 11 November 2019 Accepted : 17 Februari 2020 


\section{PENDAHULUAN}

SMK Ketintang Surabaya berdiri sudah cukup lama dan termasuk SMK yang favorit karena siswanya yang sudah cukup banyak yaitu saat ini sejumlah 961 siswa dengan jurusan ada 5 yaitu jurusan Administrasi perkantoran, jurusan akuntansi, jurusan pemasaran, jurusan multimedia serta jurusan teknik komputer dan jaringan. Jurusan Akuntansi saat ini siswanya berjumlah 546 orang. Pendidikan Akuntansi meliputi akuntansi perusahaan baik manufaktur atau perdagangan dan akuntansi perbankan, akan tetapi transaksi yang diajarkan masih sangat sederhana sehingga pemahaman siswa SMK Ketintang mengenai akuntansi perbankan masing kurang. SMK Ketintang Surabaya juga memiliki fasilitas laboratorium bank yang digunakan untuk praktek akuntansi perbankan, akan tetapi kapasitas ruang laboratorium bank juga masih terbatas. Selain itu, SMK Ketintang juga belum memiliki software khusus untuk transaksi perbankan baik untuk sistem online maupun sistem off line. Media yang digunakan untuk praktek di laboratorium juga masih menggunakan media Microsoft Excel sebagai media pembukuan.

Permasalahan yang dihadapi oleh SMK Ketintang Surabaya diantaranya pembelajaran akuntansi yang masih terbatas pada akuntansi perusahaan. Hal ini dikarenakan belum tersedianya guru SMK yang memiliki keahlian yang beragam termasuk akuntansi perbankan sehingga wawasan siswa dari SMK Ketintang juga masih terbatas pada pembelajaran akuntansi secara umum. Pembelajaran untuk akuntansi perbankan juga masih sedikit yaitu hanya sebatas praktek membuka tabungan yang ada di Bank Mini dari SMK. Permasalahan kedua yang dihadapi adalah media yang digunakan masih terbatas dan sederhana. Media pembelajaran yang digunakan di SMK Ketintang Surabaya adalah program Excel yang dipakai sebagai pengolah akuntansi pada komputer sehingga siswa masih belum bisa menggambarkan kondisi yang sebenarnya di perbankan misalnya perusahaan menarik dana ke Bank menggunakan cek atau menyetorkan dana ke Bank menggunakan media slip setoran. Hal ini juga terkait dengan sistim pembukuan yang ada di Bank Mini SMK Ketintang Surabaya yang masih semi manual.
Peran guru juga sangat penting dalam mentransfer ilmu kepada siswa SMK. Oleh karena itu, perlu adanya tambahan wawasan dan pengetahuan baru terkait dengan akuntansi perbankan serta proses operasional transaksi yang ada di bank bagi Guru SMK Ketintang Surabaya. Kegiatan pengabdian masyarakat ini bertujuan untuk memberikan pemahaman dan tambahan wawasan bagi guru SMK Ketintang Surabaya mengenai transaksi akuntansi perbankan yang ada di bank konvensional.

Beberapa kegiatan pelatihan di bidang akuntansi dan perbankan telah dilakukan oleh beberapa pengabdi sebelumnya diantaranya Hairunisya, N dan Subiyantoro, H (2016), Bachmid,F.S (2017), Larasati, M dan Sumardi (2018), Widaninggar, N dan Sari, N.K (2018). Pardede, H. D (2018).

Hairunisya, $\mathrm{N}$ dan Subiyantoro, $\mathrm{H}$ (2016) telah melakukan kegiatan pengabdian masyarakat berupa pelatihan dan pendampingan pembuatan laporan keuangan kepada pengusaha UMKM di Kecamatan Karangrejo Kabupaten Tulungagung. Berdasarkan kegiatan pelatihan tersebut, para pengusaha mulai memahami bagaimana mencatat transaksi dan membuat laporan keuangan agar pihak bank bahwa kegiatan usaha layak untuk didanai.

Bachmid, F.S (2017) mengemukakan bahwa melalui kegiatan pelatihan maka peserta pelatihan mampu menjelaskan makna akuntansi secara umum dan spesifik. Selain itu melalui kegiatan pelatihan dapat menambah ilmu dan wawasan bagi para peserta (Pardede, H. D, 2018).

Hasil pengabdian masyarakat yang dilakukan oleh Widaninggar, N dan Sari, N.K (2018) menunjukkan bahwa kegiatan pelatihan dan pendampingan difokuskan pada penerapan dasar-dasar akuntansi menggunakan sistem terkompuuterisasi sederhana serta penyusunan laporan keuangan. Kegiatan tersebut telah berhasil membangun suatu sistem pelaporan keuangan yang berbasis web.

Larasati, M dan Sumardi (2018) telah melakukan kegiatan pengabdian masyarakat tentang pelatihan akuntansi lembaga keuangan syariah bagi siswa di SMK Plus Ashabulyamin Kabupaten Cianjur. Hasil pengabdian masyarakat tersebut memberikan kontribusi nyata untuk meningkatkan minat, pengetahuan dan kemampuan atas akuntansi syariah bagi para siswa. 


\section{METODE}

Metode kegiatan pengabdian masyarakat ini adalah berupa pelatihan yang terdiri dari penjelasan secara teori dan praktek mengenai transaksi akuntansi perbankan di bank konvensional. Kegiatan praktek transaksi meliputi pengerjaan soal akuntansi bank, pengisian media atau slip transaksi dan melakukan input jurnal transaksi pada software bank konvensional (Instruktur Laboratorium Bank, 2016: 28-121). Kegiatan ini diikuti oleh 10 orang guru akuntansi SMK Ketintang Surabaya.

\section{HASIL DAN PEMBAHASAN}

Pada kegiatan pengabdian masyarakat ini, peserta memperoleh materi tentang pengenalan akuntansi perbankan secara umum. Adapun transaksi yang diberikan meliputi transaksi penghimpunan dana, transaksi penyaluran dana, dan transaksi jasa bank yaitu transfer. Dari setiap soal transaksi yang telah diberikan, para peserta akan membuat jurnal transaksinya kemudian menyiapkan dan mengisi lengkap slip transaksi terkait dengan transaksi. Setelah slip transaksi disiapkan, maka setiap peserta melakukan input transaksi pada software bank konvensional. Semua transaksi yang telah diinput melalui software perbankan kemudian dicetak laporan keuangannya. Hasil pelatihan ini menunjukkan bahwa setiap peserta mampu membuat jurnal, mengisi slip transaksi dan melakukan input transaksi di komputer.

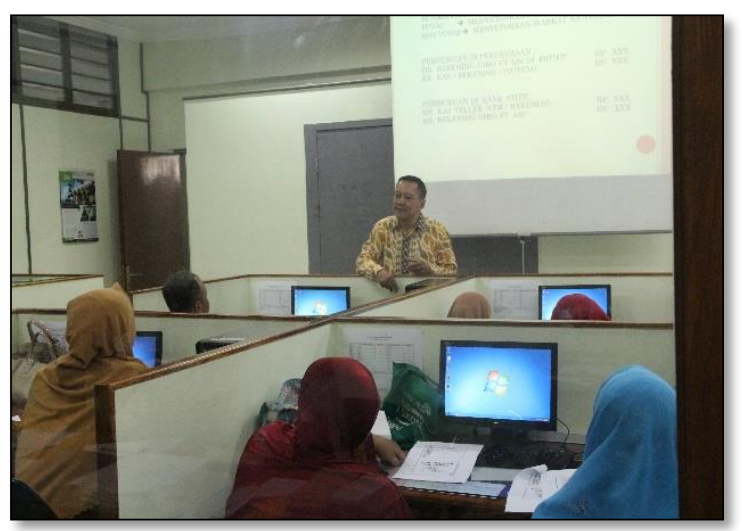

Gambar 1. Penjelasan Materi

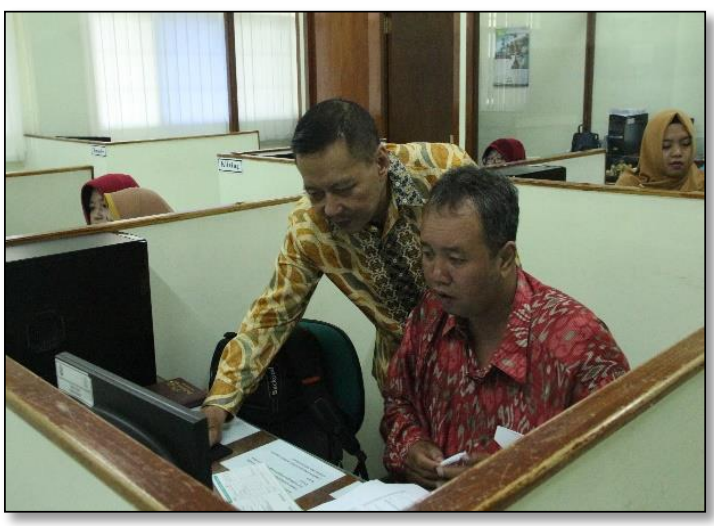

Gambar 2. Praktek Input Transaksi

Dari kegiatan ini, para peserta memahami alur transaksi akuntansi perbankan untuk setiap transaksi yang ada di bank konvensional. Hasil pengabdian ini sejalan dengan kegiatan pengabdian masyarakat yang telah dilakukan oleh Hairunisya, N dan Subiyantoro, H (2016), Bachmid,F.S (2017), Larasati, M dan Sumardi (2018), Widaninggar, N dan Sari, N.K (2018). Pardede, H. D (2018) bahwa peserta memiliki pemahaman dan keterampilan yang baik setelah dilakukan pelatihan.

Evaluasi kegiatan ini dilakukan setelah kegiatan pelatihan selesai. Dari 10 orang peserta pelatihan, hanya 8 orang yang mengumpulkan evaluasi kegiatan. Penilaian kegiatan terdiri dari penyelenggaraan, fasilitas dan materi. Komponen penyelenggaraan terdiri dari metode pelatihan, koordinasi pelaksanaan, kerjasama panitia dengan peserta. Komponen fasilitas pelatihan terdiri dari kondisi ruangan, pengaturan tempat duduk, sound system, seminar kit, dan konsumsi. Sedangkan komponen materi terdiri dari kualitas materi secara keseluruhan, aktualisasi materi, kebaruan materi, dan kualitas pembawa materi. Peserta menilai komponen penilaian tersebut dengan score 1-5.

Berdasarkan hasil penilaian diketahui bahwa rata-rata penilaian secara keseluruhan adalah 3.97 (cukup baik). Peserta menilai bahwa waktu yang dibutuhkan untuk pelatihan masih kurang. Hal ini karena waktu yang terbatas mengingat ruang laboratorium akan digunakan untuk perkuliahan kelas regular dan pelaksanaan pelatihan juga dilakukan pada hari kerja. Rincian penilaian dari peserta pelatihan dapat dilihat pada gambar 3 . 


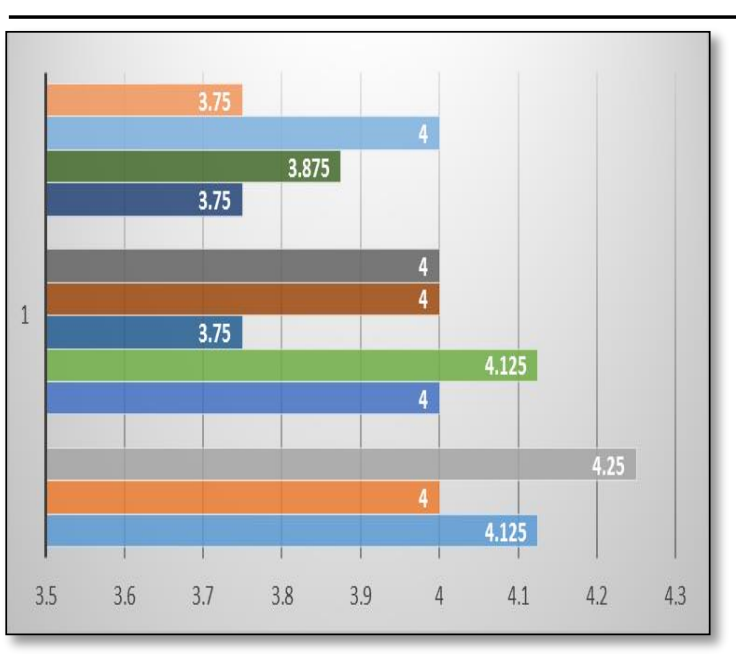

Gambar 3. Evaluasi Kegiatan

Kendala selama kegiatan berlangsung adalah terlambatnya peserta saat pelatihan sehingga waktu pelaksanaan menjadi mundur. Selain itu, terdapat keterbatasan waktu penggunaan laboratorium Bank karena laboratorium bank akan digunakan untuk kegiatan perkuliahan regular sehingga materi yang disampaikan juga terbatas. Kendala mengenai waktu juga dihadapi oleh Bachmid,F.S (2017) dalam kegiatan pengabdian masyarakatnya.

\section{SIMPULAN}

Berdasarkan hasil pelatihan akuntansi perbankan, guru SMK Ketintang Surabaya dapat memahami dan mengetahui alur praktek transaksi akuntansi bank yang ada di bank konvensional mulai dari pengisian slip transaksi sampai dengan menginput jurnal transaksi di komputer. Hasil evaluasi kegiatan yang dilakukan oleh guru SMK Ketintang Surabaya juga memberikan hasil yang baik.

\section{DAFTAR PUSTAKA}

Bachmid, F.S. (2017). Pelatihan Akuntansi Berbasis Sistem Informasi Akuntansi. Jurnal Dharma Bhakti Ekuitas, 01(02), 26-32.

Hairunisya, N \& Subiyantoro, H. (2016). Pelatihan dan Pendampingan Pembuatan Laporan Keuangan Kepada Pengusaha UMKM di Kecamatan Karangrejo Kabupaten Tulungagung. J-ADIMAS (Jurnal Pengabdian Kepada Masyarakat), 4(02), 31-41.

Pardede, H. D., Simarmata, H. M. P., Saragih, R.S., Panjaitan, R.E. (2018). Pelatihan dan Pendampingan Pembuatan Laporan Keuangan Petani Jamur di Kecamatan Sitalasari Pematangsiantar. Caradde: Jurnal Pengabdian Masyarakat, 1(1), 57-61. : https://doi.org/10.31960/caradde.v1i1. 8.

Instruktur Laboratorium Bank. (2016). Modul Klasikal Laboratorium Operasional Bank. Surabaya: STIE Perbanas Surabaya.

Larasati, M \& Sumardi. (2018). Pelatihan Akuntansi Lembaga Keuangan Syariah Bagi Siswa di SMK Plus Ashabulyamin Kabupaten Cianjur. SYUKUR (Jurnal Inovasi Sosial dan Pengabdian Kepada Masyarakat), 1(2), 168-177. https://doi.org/10.22236/syukur_vol1/i s2pp168-177

Widaninggar, N \& Sari, N.K. (2018). Penerapan Sistem Akuntansi Dasar dan Pelaporan Keuangan KPRI Kencana. Jurnal Pengabdian Masyarakat Ipteks, 4(2), 102-109. 